\title{
Rapid recovery of fauna following simulated ice rafting in a Nova Scotian seagrass bed
}

\author{
Friederike I. Schneider ${ }^{1}$, Kenneth H. Mann ${ }^{2, *}$ \\ ${ }^{1}$ Department of Biology, Dalhousie University, Halifax, Nova Scotia, Canada B3H 4 J1 \\ ${ }^{2}$ Department of Fisheries and Oceans, Habitat Ecology Division, Bedford Institute of Oceanography, PO Box 1006, Dartmouth, \\ Nova Scotia, Canada B2Y 4A2
}

\begin{abstract}
The shallow portion of the seagrass, Zostera marina L., bed in Pomquet Harbour, Nova Scotia, Canada, is subject to patchy disturbance by ice rafting, in which areas of seagrass are frozen into the underside of ice, which breaks up into large pieces and floats away. To examine the potential effect of small-scale removal of patches of eelgrass on the seagrass fauna, ice rafting was simulated by clearing $1.2 \times 0.4 \mathrm{~m}$ patches in the spring. Eelgrass recovery on the experimentally cleared patches was relatively slow, and 4 mo later the biomass was still significantly lower on the cleared patches than in the surrounding seagrass bed. In contrast, recovery of macroalgae was much more rapid, biomass approximating control levels by $1.5 \mathrm{mo}$ after disturbance. Clearing also had a relatively short-lived effect on most invertebrate species, numbers of all species on the cleared patches being at or above those in the surrounding seagrass bed 3 to 4 mo after clearing. The recovery of epifauna was significantly linked to macroalgal biomass on cleared patches, indicating that the rapid return of macroalgae to cleared patches enabled this community to recover rapidly after disturbance despite the slower seagrass recovery.
\end{abstract}

\section{INTRODUCTION}

Disturbance is widely acknowledged to have a fundamental effect in many communities (White \& Pickett 1985). Most studies have focussed on communities of sessile organisms, in which disturbance often creates open areas by the removal of established individuals, permitting colonization by other species. This pattern has been observed in a wide variety of systems including marine intertidal macroalgae (Sousa 1985, Heine 1989), salt marshes (Bertness \& Ellison 1987), grasslands (Hobbs \& Mooney 1985), and temperate forests (Runkle 1985), though sometimes the previous occupant recovers first and no change in species composition is observed (Dethier 1984, Kennelly 1987). Smallscale disturbances remove only a few individuals at a time, producing a heterogeneous mosaic of patch types, the character of each reflecting its history of disturbance and its course of recolonization (Sousa 1979, Runkle 1985). The effect of small-scale disturbances on mobile animals, either through direct detrimental effects on populations or indirect effects via altera-

- Addressee for correspondence

(C) Inter-Research/Printed in Germany tion in vegetation habitat, has received less attention The latter effect is the focus of this study.

Macrophytes in vegetated aquatic systems provide much of the physical infrastructure upon which the system is based; indicative of this close relationship is the observation that invertebrate abundance and diversity can often be related to macrophyte biomass (Heck \& Orth 1980, Stoner 1980, Bronmark 1985, Friday 1987). In these systems, studies of animal responses to varying vegetation composition have focussed on selection based on feeding (Nicotri 1980, Norton \& Benson 1983, Hay et al. 1988) or on suitability as habitable space. Many animals are dependent upon the presence of refuges both from physical effects, such as water currents (Orth 1977, McRoy \& Helfferich 1980), and from predators (Crowder \& Cooper 1982, Summerson \& Peterson 1984, Joyce \& Weisberg 1986).

Disturbances not only alter the amount of vegetation, but also its patchiness. There are few studies of the response of mobile animals to gaps in vegetation cover in aquatic systems, but many terrestrial species forage selectively in gaps (Mills 1986, Crome \& Richards 1988). There is some indication that animals in seagrass beds migrate to open areas both within and outside the 
bed (Holt et al. 1983, Summerson \& Peterson 1984) and that bare areas may function as predator feeding loci in seagrass beds (Heck \& Orth 1980 ) and salt marshes (Zimmerman \& Minello 1984)

Seagrass systems are subject to a variety of natural small-scale disturbances including ice scouring (Robertson \& Mann 1984, Schneider 1990), wave-generated erosion (Patriquin 1975) and herbivore feeding (Orth 1977. Williams 1988), but little attention has been paid to effects on mobile animals. It has been widely demonstrated that faunal densities and species diversity are much higher in seagrass beds than in adjacent unvegetated areas (Stoner 1980, Orth et al. 1984, Summerson \& Peterson 1984). This relationship has been attributed to the effects of seagrasses on physical characteristics, such as current speed and sediment stability (Orth 1977, Peterson et al. 1984), or modification of biotic interactions such as predation (Nelson 1979, Heck \& Thoman 1981, Summerson \& Peterson 1984). Invertebrate assemblages also vary between areas of different seagrass species (Lewis 1984, Virnstein \& Howard 1987a), between seagrass plants and bare areas (Lewis \& Stoner 1983), and between seagrass and macroalgae (Lewis 1987. Virnstein \& Howard 1987b, Schneider \& Mann 1991a). This variation among microhabitats has been linked to differences in predation, food availability, and other species-specific habitat requirements (Heck \& Orth 1980, Coen et al. 1981, Leber 1985, Schneider \& Mann 1991b). Given this effect on a small habitat scale, disturbanceinduced changes in vegetation cover should have a significant effect on invertebrate distribution.

An eelgrass bed in Pomquet Harbour, Nova Scotia, Canada, was chosen for study of disturbance by ice. The harbour is covered with ice up to $0.7 \mathrm{~m}$ thick from January to mid-March. The rise and fall of the tide has the effect of breaking the ice into sections, or 'pans' each having a surface area of one to a few $\mathrm{m}^{2}$. In shallow water these pans freeze to the eelgrass and sediment surface at low tide, but when the tide rises they may lift a patch of eelgrass, complete with rhizomes and roots, out of the sediment. In spring, when the ice began to break up, it was found that a number of pans were moving away with eelgrass frozen into their undersides. This is known as 'ice rafting'.

Examination of the eelgrass bed revealed bare patches from which all eelgrass, including rhizomes and roots, had been removed. In spring, the patches were most abundant in a zone $2 \mathrm{~m}$ wide parallel with the inshore edge of the eelgrass bed (which was at mean high tide level). In a zone $3 \mathrm{~m}$ further into the eelgrass bed (mean depth $0.5 \mathrm{~m}$ at mid-tide) the frequency of bare patches decreased, and in the next $3 \mathrm{~m}$ wide zone (mean depth $0.8 \mathrm{~m}$ ) the incidence of bare patches decreased to zero.
Confirmation that the bare patches were caused by ice rafting in winter was obtained by aerial photography from a light plane in spring and fall of 1987 and 1988. In the most shallow edge zone the proportion lacking eelgrass cover was $55 \%$ in spring 1987 , decreasing to $35 \%$ in fall and increasing to $67 \%$ the following spring. In the next zone the figures were 29 , 2 and $28 \%$. In the deepest of the 3 zones the figures were 7,0 and $2 \%$.

In an attempt to understand the dynamics of this process, and especially the effect of patch formation on the flora and fauna, ice rafting was mimicked by creating artificial patches of a standard size and comparing them at intervals with control patches with full eelgrass cover

\section{METHODS AND MATERIALS}

Study site. The study site was situated in an eelgrass, Zostera marina, bed on a muddy sand sediment in the sheltered inner basin of Pomquet Harbour, Nova Scotia $\left(45^{\circ} 50^{\prime} \mathrm{N}, 61^{\circ} 90^{\prime} \mathrm{W}\right)$. The eelgrass bed contains large quantities of macroalgae, especially Chondrus crispus and Gracilaria tikvahiae, year round, and Polysiphonia urceolata and Sphaerotrichia divaricata in the summer. The first 2 species usually intermingle in freely drifting balls, while the latter 2 are typically epiphytic on larger macrophytes. When Sphaerotrichia occurs in large quantities it may break off and drift about as unattached clumps. A complete site description can be found in Schneider \& Mann (1991a).

Selection of artificial patch size. Since natural patches differed in size, shape and location, replicated, standardized artificial gaps in the eelgrass cover were created. It was desirable to produce artificial cleared patches within the size range normally produced by ice scour. A survey of natural bare patches was conducted in early April 1986 along a $155 \mathrm{~m}$ transect within a $5 \mathrm{~m}$ wide strip along the inshore edge of the eelgrass bed. The longest axis of unvegetated patches and the maximum width perpendicular to this axis were found to average $1.2 \mathrm{~m}$ (range 0.3 to $2.3 \mathrm{~m}$ ) and $0.6 \mathrm{~m}$ (range 0.1 to $1.0 \mathrm{~m}$ ). Because these represented maximum dimensions, a rectangular patch of $1.2 \times 0.6 \mathrm{~m}$ would have a greater area than the average of the natural patches Therefore slightly smaller rectangular patches of $1.2 \times$ $0.4 \mathrm{~m}$ were experimentally created.

Experimental protocol. The experiments were conducted in a plot which extended $40 \mathrm{~m}$ along the shore, with its inner edge $5 \mathrm{~m}$ and its outer edge $11 \mathrm{~m}$ from the shore. It was divided longitudinally into a shallow zone extending 5 to $8 \mathrm{~m}$ from shore, with a mean depth of $0.8 \mathrm{~m}$, and a deep zone 8 to $11 \mathrm{~m}$ from shore, with a mean depth of $1.0 \mathrm{~m}$. The shallower of these 2 areas 
corresponded to the depths where scouring still occurred, but not extensively, while no ice-rafted patches were observed in the deeper zone. The overall $40 \times$ $6 \mathrm{~m}$ plot was divided into 160 sampling units of $1.5 \times$ $1 \mathrm{~m}$. Of these 45 were randomly chosen to be manipulated and 45 as controls, with equal numbers in the shallow and deep zones. The sampling time of each was randomly assigned to one of 3 dates. Following the recommendation of Hurlbert (1984), adequate interspersion of treatments along the long axis of the plot was assured by constraining randomization such that equal numbers of replicates were collected from each half of the plot.

Experimental clearing was conducted during the month after ice breakup, i.e. in May 1986. The margins of the patches to be cleared were marked with a rope, the eelgrass rhizomes entering the patch were cut with a knife, and then eelgrass shoots, macroalgae and eelgrass rhizomes were removed with a hand rake. This procedure removed most epifauna along with the above-ground vegetation and many infauna with the eelgrass rhizomes. As this situation was thought to mimic natural ice rafting of vegetation, no attempt was made to dig out any remaining infauna. The 4 corners of the cleared patches were marked with stakes so that they could be found at later dates.

Samples were collected from the centers of cleared patches and control units. Infaunal samples were taken with a $10 \mathrm{~cm}$ diameter clear plastic corer inserted $15 \mathrm{~cm}$ into the sediment in June and August 1986. Epifaunal samples were taken with a sampler based on the design of Virnstein \& Howard (1987a), which consisted of 2 halves of a $30 \times 30 \mathrm{~cm}$ box, $10 \mathrm{~cm}$ wide in total, connected by a piano hinge at one end (Fig. 1). The sampler frame was constructed of $5 \mathrm{~cm}$ wide strips of aluminum and the large sides of each half were covered with $1.0 \mathrm{~mm}$ plastic mesh. Samples were collected while wading or snorkeling. The use of a face mark permitted observation of the sample collection procedure to ensure that no vegetation slipped out of the sampler. The sampler was placed with the hinged end perpendicular to the bottom, opened $30 \mathrm{~cm}$ and moved forward $30 \mathrm{~cm}$. Care was taken to keep the sampler off the sediment and, after the sampler was closed, all external vegetation was clipped off. In this manner, the invertebrates within a single sample were directly associated with the vegetation enclosed, and uniform, quantitative samples were collected each time. The sampler enclosed a total volume of $0.012 \mathrm{~m}^{3}$, associated with $0.039 \mathrm{~m}^{2}$ of bottom. Because the comparisons of interest were between numbers in control and manipulated samples, all animal numbers and emergent macrophyte biomass were reported on a per sample basis. Epifaunal samples were taken in July and September 1986 and again in July 1987

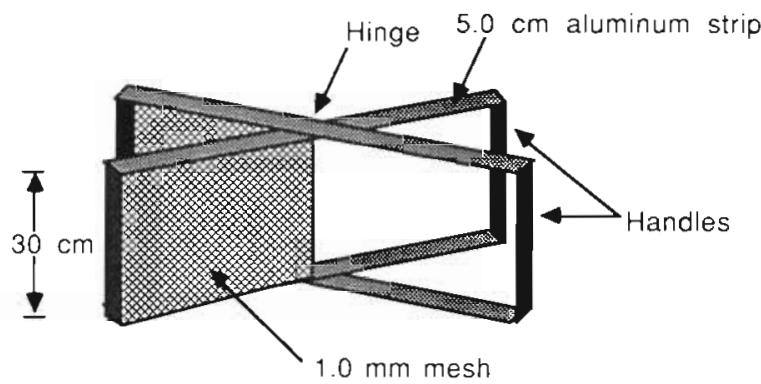

Fig. 1 Sampler used to collect epifauna and vegetation

Infaunal samples were washed through $1.0 \mathrm{~mm}$ sieves and the epifaunal samples through $0.5 \mathrm{~mm}$ sieves (the smaller mesh size reduced damage to delicate amphipods caused by washing). Vegetation and animals longer than $1 \mathrm{~mm}$ retained on the screens were frozen until sorted. Changes in biomass of the major vegetation types subsequent to the initial clearing were estimated from the amount of vegetation collected in the epifaunal sampler. Vegetation was sorted into 3 categories: (i) eelgrass, (ii) coarsely branched algae (Chondrus crispus and Gracilaria tikvahiae), and (iii) finely branched algae (mainly Sphaerotrichia divaricata), and dried to constant weight at $80^{\circ} \mathrm{C}$.

Statistical analysis. To minimize the effects of seasonal changes in the abundance of organisms, the analysis was concentrated on a comparison of manipulated and control plots on each sampling date. For each data set (vegetation biomass, epifaunal numbers, infaunal numbers) analysis of variance, ANOVA, was performed using treatment (cleared vs control), depth zone (shallow vs deep), and time (since experimental clearing) as factors. All data were transformed $\ln (Y+1)$ and Bartlett's test for homogeneity of variances showed that this procedure successfully standardized variances. ANOVA revealed which factors produced significant effects in the experiment as a whole. A posteriori pairwise Scheffé contrasts between cleared and control patches from the same depth zone and date were used to assess significant differences when ANOVA showed significant interactions with treatment main effects.

To determine the direct relation of animal numbers on experimentally cleared patches to vegetation biomass within the same patches, regression analyses were conducted on samples from the cleared patches (all dates were pooled). For both the infaunal and epifaunal samples, the dependent variable was animal number $[\ln (Y+1)$ transformed to stabilize variances] and the independent variable was vegetation biomass (dry wt).

To determine whether species too rare to be examined individually were affected by experimental clearing, patterns of variation in the total invertebrate 
community were described using principal components analysis, PCA. Data were transformed $\ln (Y+1)$ as recommended by Pielou (1984) and plotted separately for cleared and control samples and for shallow and deep zones, according to their scores along the first 2 axes of the PCA. Separation among groups was estimated by visual inspection and mean factor scores were compared by ANOVA. The contribution of individual species to the patterns was assessed by examination of the species' loading along the factors of interest. Since animals were collected by both epifaunal and infaunal (core) samplers, the 2 sets of data were analyzed separately. Thus, 12 species are included in the epifaunal analysis and 7 in the infaunal. Three species normally classed with the infauna, Gemma gemma, Mytilus edulis and Nereis succinea, were also included in the epifaunal analysis (in the PCA only) because they are abundant in the vegetation and debris at the sediment-water interface and occurred abundantly in the samples collected by the epifaunal sampler.

A potential problem of PCA in many ecological applications is that its linear model assumes that species abundances change linearly along underlying gradients. Distortions are produced if this assumption is violated (Pielou 1984, Austin 1985). We had shown previously (Schneider \& Mann 1991a) that the principal source of variation in animal abundance at a given time was a linear response to vegetation biomass, so the requirements of the method were met.
For comparison of faunal diversity on cleared and control areas 2 measures were calculated: the total number of species (species richness) and a modified Shannon-Wiener index (Peet 1974)

$$
H^{\prime}=\exp \left(-\sum_{i=1}^{s} p_{i} \ln p_{i}\right)
$$

where $s$ is the total number of species and $p_{i}$ is the proportion of total individuals belonging to the $i$ th species.

\section{RESULTS}

\section{Vegetation recovery on manipulated patches}

Recovery of eelgrass after experimental clearing was relatively slow (Fig. 2). It appeared to be entirely by lateral growth of plants at the edges, for no seedlings were found. After $1.5 \mathrm{mo}$ the average biomass of eelgrass had reached only 3 to $4 \%$ of the control values, and at the end of the summer considerable differences were still present. Even in July of the following year, eelgrass biomass on the cleared patches in the shallow zone was only one third of control values. This did not represent 14 mo of continuous regrowth as all plants shed large numbers of leaves in late fall and began to grow again in spring.

Analysis of variance (Table 1) showed that the differences between treated and control patches were highly
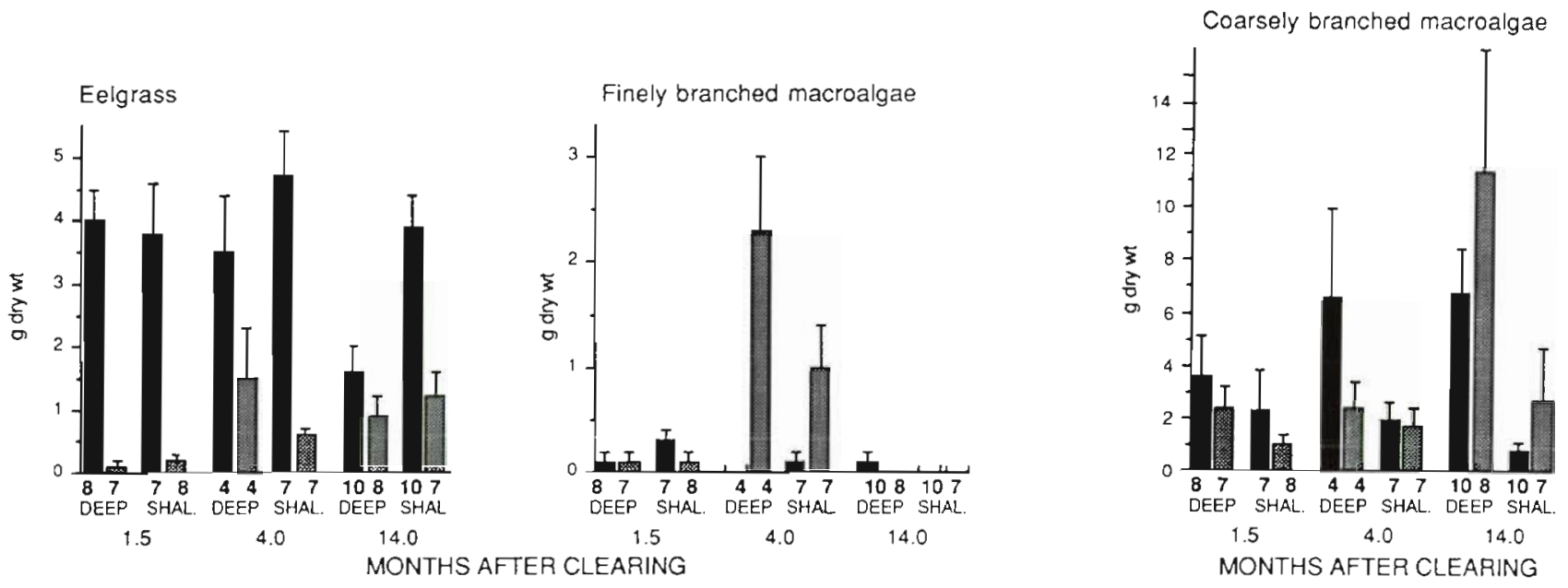

CONTROL
CLEARED
Fig. 2. Vegetation biomass (g dry wt $\pm 1 \mathrm{SE}$ per sample) on control and experimentally manipulated patches. 'Deep' and 'Shal.' (shallow) are the 2 depth zones. Number of replicates is shown beneath each column 
Table $1 F$-values of ANOVA comparing vegetation biomass between control and experimentally cleared patches. ANOVA was performed on $\ln (Y+1)$ transformed macrophyte dry weights using the following factors: 'Time' = time of sampling; 'Depth' = position in either shallow or deep zone; and 'Trt' $=$ treatment, i.e. experimentally cleared vs control. Total $n=87 ; \cdots p 0.01$; $\cdot 0.01<\mathrm{p}<0.05$

\begin{tabular}{|c|c|c|c|c|c|c|c|}
\hline & Time & Depth & $\operatorname{Trt}$ & $\begin{array}{l}\text { Time } \times \\
\text { Depth }\end{array}$ & $\begin{array}{c}\text { Time } \\
\text { Trt }\end{array}$ & $\begin{array}{c}\text { Depth } \\
\text { Trt }\end{array}$ & $\begin{array}{c}\text { Time } \times \\
\text { Depth } \times \\
\text { Trt }\end{array}$ \\
\hline Degrees of freedom & 2 & 1 & 1 & 2 & 2 & 1 & 2 \\
\hline Eelgrass & 2.84 & 1.91 & $118.2^{\cdots}$ & $3.1^{\circ}$ & $9.9^{*}$ & 3.4 & 2.0 \\
\hline Coarsely branched algae & 0.5 & $13.2^{\cdots}$ & 0.3 & 1.7 & 0.5 & 0.2 & 0.1 \\
\hline Finely branched algae & $24.3 \cdots$ & 2.8 & $23.1 \cdots$ & $3.0^{\circ}$ & $32.8 \cdots$ & $45^{\circ}$ & $4.0^{\circ}$ \\
\hline
\end{tabular}

Table 2. F-values of a posteriori Scheffé contrasts comparing vegetation biomass on control and experimentally cleared patches within depth zones at single sampling times. Values were $\ln (Y+1)$ transformed macrophyte dry weights. $\cdots p<0.01$; $\cdot 0.01<\mathrm{p}<0.05$

\begin{tabular}{|c|c|c|c|c|c|c|}
\hline & \multicolumn{2}{|c|}{ July 1986} & \multicolumn{2}{|c|}{ September 1986} & \multicolumn{2}{|c|}{ July 1987} \\
\hline & Deep & Shallow & Deep & Shallow & Deep & Shallow \\
\hline Eelgrass & $51.8^{\cdots}$ & $42.2^{\cdots}$ & $6.2^{\circ}$ & $33.2^{*}$ & 1.4 & $17.5^{\cdots}$ \\
\hline Coarsely branched algae & 0.1 & 0.3 & 0.5 & 0.1 & 0.1 & 0.3 \\
\hline Finely branched algae & 0.1 & 1.9 & $53.8^{\cdots}$ & $21.5^{\circ}$ & 0.6 & 0.1 \\
\hline
\end{tabular}

significant. Pairwise contrasts showed that eelgrass biomass differed significantly between control and cleared patches at all depths and times except for the deep zone in July 1987 (Table 2). The time $\times$ treatment interaction was also significant and this is in part due to the significant changes in eelgrass biomass on both deep and shallow treated plots between July and September 1986 (a posteriori pairwise contrasts, $\mathrm{p}<0.01$ ).

In contrast, recovery of coarsely branched algae on the cleared patches was relatively rapid (Fig. 2). Analysis of variance (Table 1) showed no significant differences between manipulated and control patches at any sampling date.

Finely branched macroalgae were present in very small amounts at most sampling times, though there was a marked bloom on the cleared patches in September 1986 (Fig. 2). Analysis of variance (Table 1) showed a significant main treatment effect and significant time $x$ treatment interaction. Pairwise contrasts showed that finely branched macroalgal biomass differed significantly between control and treated plots only in September 1986 (Table 2). The difference occurred in both deep and shallow zones.

\section{Comparison of animal abundances on control and manipulated patches}

The abundances of total epifauna (all crustaceans and gastropods collected in the epifaunal sampler), total infauna (all bivalves and annelids collected in the infaunal sampler), and 6 individually abundant invertebrate species on the cleared and control patches are shown in Figs. $3 \& 4$.

Total epifaunal numbers were significantly decreased by clearing only on the first sampling date, 1.5 mo after clearing (significant time $\times$ treatment interaction, Table 3a; significant contrasts for July 1986 in both depth zones, Table 4a). Likewise, 2 of the individual epifaunal species examined, the tubedwelling amphipod Ampithoe (primarily A. longimana though some A. rubricata were present) and the herbivorous snail Bittium alternatum, were significantly less abundant on manipulated than on control patches in the same depth zone 1.5 mo after clearing (significant treatment main effect and/or significant time $x$ treatment interaction, Table 3a; significant contrasts for July 1986 in both depth zones, Table 4a). Four months after clearing no significant differences were observed. In contrast, the average abundance of the free-swimming amphipod Gammarus mucronatus tended to be very similar in manipulated and control plots, and analysis of variance showed no significant treatment effects.

Infaunal abundances were less affected by experimental clearing than the epifauna. For total infaunal numbers, neither the treatment main effect nor interactions involving treatment were significant (Table 3b). The polychaete Nereis succinea was significantly less abundant on cleared patches (in the shallow zone) on 

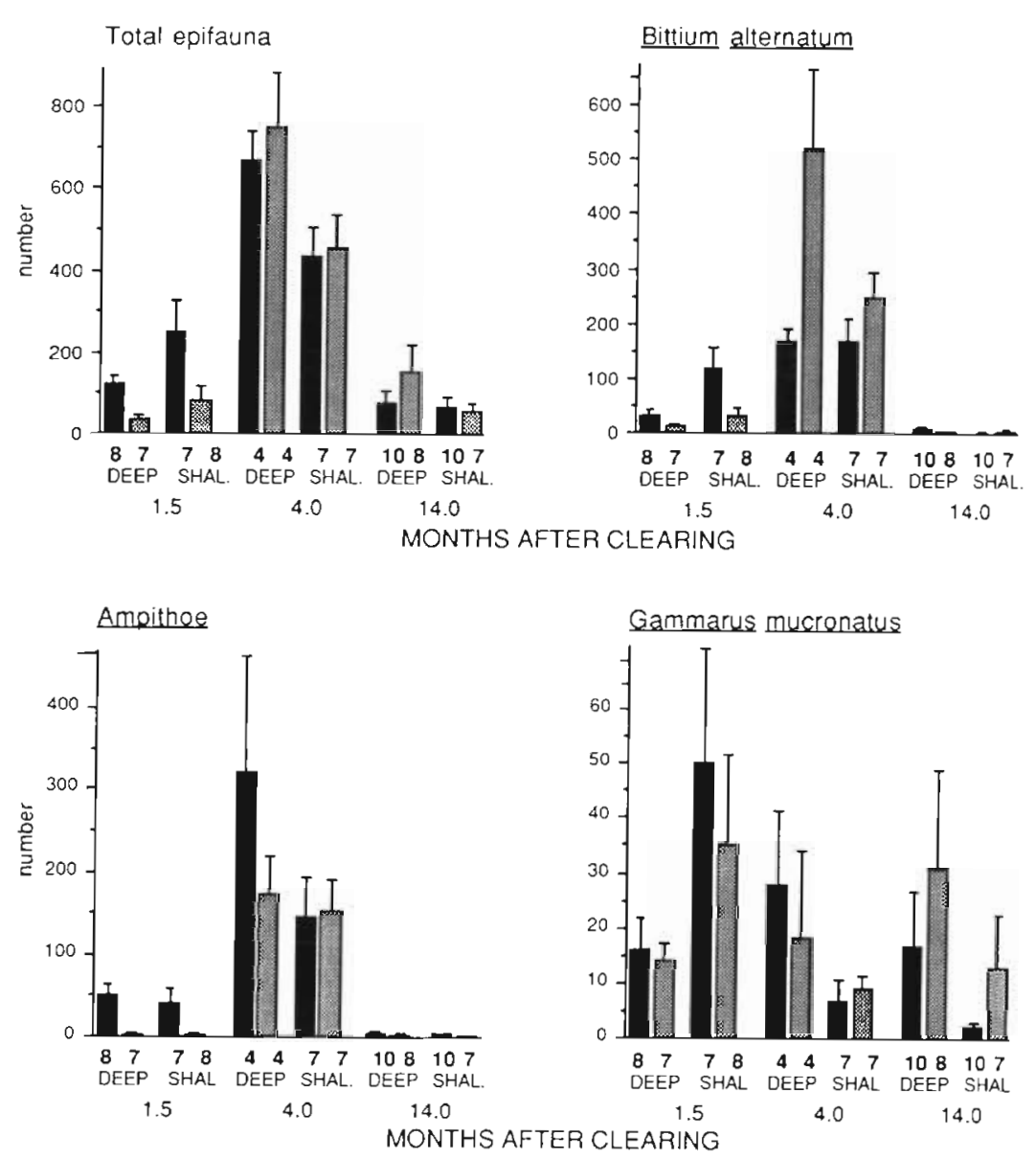

Fig. 3. Abundances (numbers \pm 1 SE per
sample) of total epifauna and selected indi-
vidual species on control and experimentally
manipulated patches. 'Deep' and 'Shal.'
(shallow) are the 2 depth zones. Number of
replicates is shown beneath each column the first sampling date (significant treatment main effect and time $x$ treatment interaction, Table $3 b_{\text {; }}$ significant contrast for July 1986 in shallow zone, Table 4 b). Tellina agilis displayed no significant differences between control and experimental patches.

Gemma gemma differed from all other species in that the average numbers in the cleared patches were significantly greater than in the controls (significant treatment effects, Table 3b). Numbers in the shallow zone were also consistently higher than in the deep (significant depth effect, Table 3b). In terms of individual pairwise comparisons between cleared and control patches, only the difference 3.0 mo after clearing in the shallow zone was significant (Table 4 b).

\section{Relationship of animal abundances to vegetation biomass on experimentally cleared patches}

Regression analysis showed that total epifaunal numbers on experimentally cleared patches were signifi- cantly related to the biomass of finely branched algae There was a weak relationship with coarsely branched algae and no relation to eelgrass biomass (Table 5a) Examination of individual epifaunal species showed a strong relationship between the abundances of both Bittium alternatum and Ampithoe spp. and the biomass of finely branched macroalgae, and between the abundance of Gammarus mucronatus and coarsely branched macroalgae. No species was positively related to eelgrass biomass (Gammarus showed a negative relationship).

In contrast, abundances of infauna were not significantly positively related to vegetation biomass within the same sample (Table 5b). In fact, total infaunal numbers were negatively related to eelgrass root biomass in core samples, probably because of the numerical dominance of Gemma gemma, which tended to be negatively related to root biomass $(0.05<p<0.10)$. The other 2 infaunal species, Nereis succinea and Tellina agilis, were not significantly related to vegetation biomass within the samples. 
CONTROL CLEARED

Fig. 4. Abundances (numbers $\pm 1 \mathrm{SE}$ per sample) of total infauna and selected individual species on control and experimentally manipulated patches. 'Deep' and 'Shal.' (shallow) are the 2 depth zones. Number of replicates is shown beneath each column

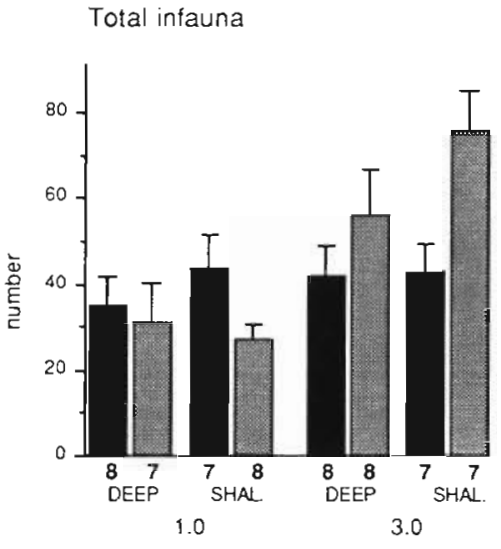

Nereis succinea

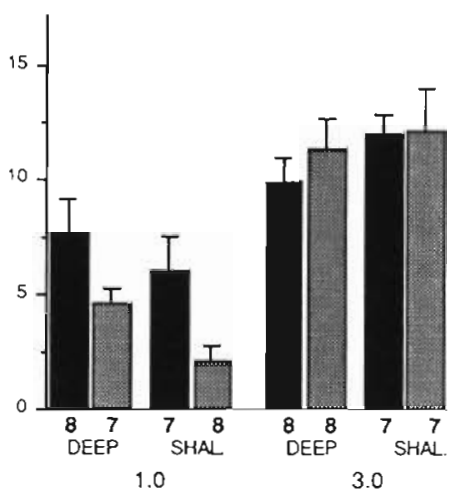

MONTHS AFTER CLEARING

Germmą gemma

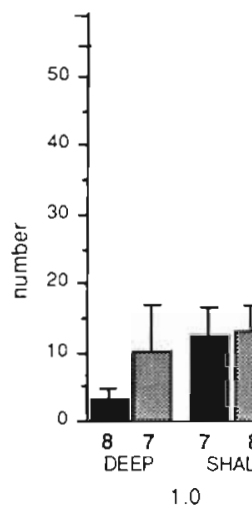

Tellina agilis

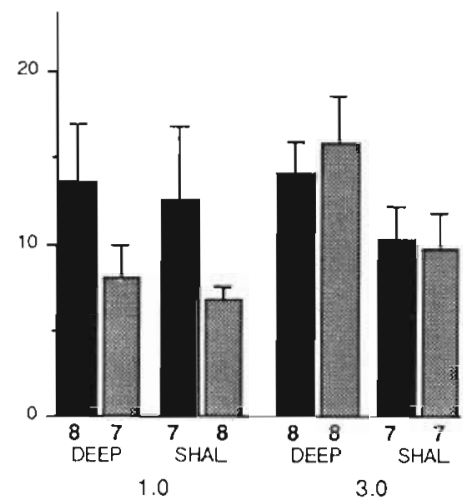

MONTHS AFTER CLEARING

Table 3. F-values obtained in an ANOVA of total epifauna, total infauna and selected individual species on control and experimentally cleared patches. ANOVA was performed on $\ln (Y+1)$ transformed animal numbers using the following factors: 'Time' = time of sampling; 'Depth' = position in either shallow or deep zone; and 'Trt' = treatment, i.e. experimentally cleared vs control. $\cdots p<0.01 ; \cdot 0.01<p<0.05$

\begin{tabular}{|c|c|c|c|c|c|c|c|}
\hline Species & Time & Depth & Trt & $\begin{array}{l}\text { Time } \times \\
\text { Depth }\end{array}$ & $\begin{array}{c}\text { Time } \\
\text { Trt }\end{array}$ & $\begin{array}{c}\text { Depth } \times \\
\text { Trt }\end{array}$ & $\begin{array}{c}\text { Time } \times \\
\text { Depth } \times \\
\text { Trt }\end{array}$ \\
\hline \multicolumn{8}{|l|}{ (a) Epifauna $(n=87)$} \\
\hline Degrees of freedom & 2 & 1 & 1 & 2 & 2 & 1 & 2 \\
\hline Total epifauna & $34.6^{\circ}$ & 0.0 & 2.5 & 2.5 & $3.0^{\circ}$ & 0.2 & 0.4 \\
\hline Ampithoe spp. & $111.4^{* *}$ & 1.6 & $23.8^{\cdots}$ & 0.8 & $14.4^{\cdots}$ & 0.3 & 0.9 \\
\hline Gammarus mucronatus & $7.7 \cdots$ & 0.4 & 0.0 & 1.9 & 0.7 & 0.2 & 0.7 \\
\hline Bittium alternatum & $122.0^{*}$ & 0.0 & 2.2 & $6.0^{-:}$ & $8.3^{\cdots}$ & 0.1 & 1.4 \\
\hline \multicolumn{8}{|l|}{ (b) Iniauna (n=60) } \\
\hline Degrees of freedom & 1 & 1 & 1 & 1 & 1 & 1 & 1 \\
\hline Total infauna & $153^{\cdots}$ & 2.0 & 0.2 & 0.1 & 9.3 & 0.0 & 1.3 \\
\hline Gemma gemma & 1.0 & $19.9^{\cdots}$ & $4.3^{\circ}$ & 0.2 & 1.1 & 0.7 & 3.1 \\
\hline Tellina agilis & 3.2 & 2.4 & 1.8 & 1.5 & 1.2 & 0.1 & 0.0 \\
\hline Nereis succinea & $54.3^{\cdots}$ & 2.1 & $6.2^{\circ}$ & $6.8^{\circ}$ & $7.5^{\cdots}$ & 1.8 & 0.5 \\
\hline
\end{tabular}


Table 4. F-values of a posteriori Scheffé contrasts comparing animal numbers on control and experimentally cleared patches within depth zones at single sampling times. Values were $\ln (Y+1)$ transformed. $\cdots p<0.01 ; \cdot 0.01<p<0.05$

\begin{tabular}{|c|c|c|c|c|c|c|}
\hline \multirow{2}{*}{ (a) Epifauna } & \multicolumn{2}{|c|}{ July 1986} & \multicolumn{2}{|c|}{ September 1986} & \multicolumn{2}{|c|}{ July 1987} \\
\hline & Deep & Shallow & Deep & Shallow & Deep & Shallow \\
\hline Total epifauna & $5.2^{\circ}$ & $3.9^{\circ}$ & 0.0 & 0.0 & 0.5 & 0.6 \\
\hline Ampithoe spp. & $35.6^{\cdots}$ & $21.1 \cdots$ & 0.4 & 0.1 & 0.1 & 1.8 \\
\hline Gammarus mucronatus & 0.1 & 0.3 & 0.9 & 0.4 & 0.6 & 0.6 \\
\hline \multirow{3}{*}{$\begin{array}{l}\text { Bittium alternatum } \\
\text { (b) Infauna }\end{array}$} & $4.9^{\circ}$ & $13.3^{\cdots}$ & 2.3 & 1.0 & 2.0 & 0.1 \\
\hline & \multicolumn{2}{|c|}{ June 1986} & \multicolumn{2}{|c|}{ August 1986} & & \\
\hline & Deep & Shallow & Deep & Shallow & & \\
\hline Total infauna & 0.7 & 3.3 & 1.3 & $5.2^{*}$ & & \\
\hline Gemma gemma & 0.9 & 0.0 & 0.1 & $7.7^{\cdots}$ & & \\
\hline Tellina agilis & 1.4 & 1.5 & 0.0 & 0.1 & & \\
\hline Nereis succinea & 2.5 & $13.3^{\circ}$ & 0.2 & 0.0 & & \\
\hline
\end{tabular}

\section{Comparison of patterns of faunal similarity among samples as determined by principal components analysis}

Species in epifaunal sampler

Principal components analysis distinctly separated control and manipulated samples 1.5 mo after clearing and average scores of these 2 groups for both Factors 1 and 2 were significantly different (Fig. 5a, significant treatment effect for July 1986, Table 6a). The samples from cleared plots occupy a distinct area characterized by low scores on Factor 1 and high scores on Factor 2. Four months after clearing, this separation cannot be made; the points are intermingled though average values of Factor 2 were still significantly different (Fig. 6b. significant treatment effect for September 1986, Table 6a). Examination of the species loadings for the first sampling date (July 1986, Table 7 a) shows that for Factor 1 all species except one had a positive loading between 0.36 and 0.86 , and the single negative value was small, contributing little to the scores. From this we see that negative scores on Factor 1 , which characterized the cleared plots after $1.5 \mathrm{mo}$, arose from the low abundance of a wide range of species rather than from a change in the balance of species. The separation along the second factor appeared to be due to greater relative proportion of certain species, such as Gemma gemma and Corophium insidiosum, in the cleared patches. For the second sampling time, the slight separation of manipulated and unmanipulated samples along the second factor was due to higher weighting of some species, such as Bittium alternatum and Ampithoe spp., which in preceding sections were demonstrated to be associated with the finely branched algae that bloomed on the cleared patches at this time.
Table 5. Results of simple regression analysis relating $\ln (Y+1)$ transformed animal numbers to dry weight of single vegetation types. Data were from cleared plots only and data from all sampling dates were pooled. $\cdots p<0.001$; $\cdots 0.001<p<0.01 ; \cdot 0.01<p<0.05 ; \div 0.05<p<0.10$

\begin{tabular}{|c|c|c|c|}
\hline & Slope & $\mathrm{R}^{2}$ & $F$-value \\
\hline \multicolumn{4}{|l|}{ (a) Epifauna ( $n=40$ ) } \\
\hline \multicolumn{4}{|l|}{ Total epifauna } \\
\hline Eelgrass & 0.09 & 0.00 & 0.1 \\
\hline Coarsely branched algae & 0.08 & 0.08 & $3.2^{+}$ \\
\hline Finely branched algae & 1.03 & 0.39 & $24.4^{\cdots}$ \\
\hline \multicolumn{4}{|l|}{ Ampithoe spp. } \\
\hline Eelgrass & 0.42 & 0.04 & 1.6 \\
\hline Coarsely branched algae & -0.01 & 0.00 & 0.04 \\
\hline Finely branched algae & 1.49 & 0.53 & $43.8 \cdots$ \\
\hline \multicolumn{4}{|l|}{ Gammarus mucronatus } \\
\hline Eelgrass & -0.70 & 0.17 & $8.1 \cdots$ \\
\hline Coarsely branched algae & 0.13 & 0.24 & $11.9^{\cdots} \cdots$ \\
\hline Finely branched algae & 0.02 & 0.00 & 0.0 \\
\hline \multicolumn{4}{|l|}{ Bittium alternatum } \\
\hline Eelgrass & 0.16 & 0.00 & 0.2 \\
\hline Coarsely branched algae & -0.03 & 0.00 & 0.2 \\
\hline Finely branched algae & 1.63 & 0.48 & $35.1 \cdots$ \\
\hline \multicolumn{4}{|l|}{ (b) Infauna $\mid \mathrm{n}=30\}$} \\
\hline \multicolumn{4}{|l|}{ Total infauna } \\
\hline Eelgrass roots & -1.50 & 0.29 & $11.2 \cdots$ \\
\hline Coarsely branched algae & 0.14 & 0.00 & 0.1 \\
\hline \multicolumn{4}{|l|}{ Gemma gemma } \\
\hline Eelgrass roots & -2.16 & 0.10 & $3.2^{-}$ \\
\hline Coarsely branched algae & -0.02 & 0.00 & 0.0 \\
\hline \multicolumn{4}{|l|}{ Tellina agilis } \\
\hline Eelgrass roots & -0.21 & 0.01 & 0.2 \\
\hline Coarsely branched algae & 0.08 & 0.00 & 0.0 \\
\hline \multicolumn{4}{|l|}{ Nereis succinea } \\
\hline Eelgrass roots & -0.61 & 0.03 & 09 \\
\hline Coarsely branched algae & 0.50 & 0.04 & 1.0 \\
\hline
\end{tabular}


a. JULY 1986

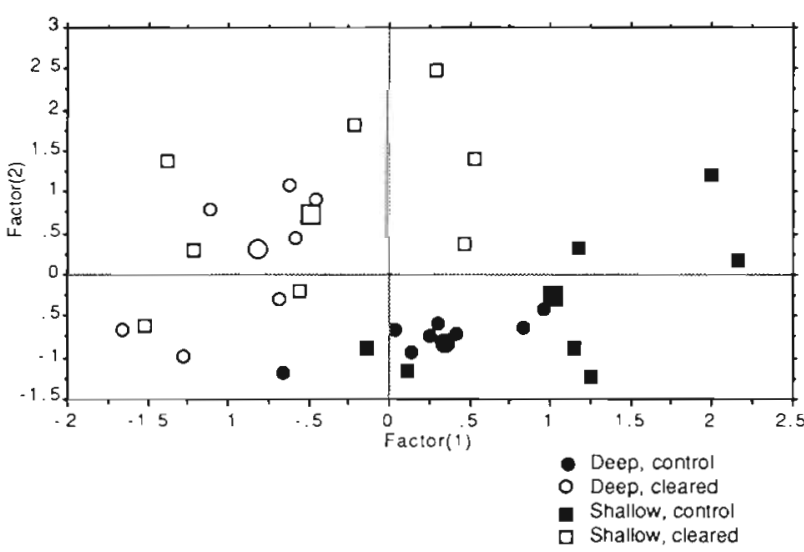

b. SEPTEMBER 1986

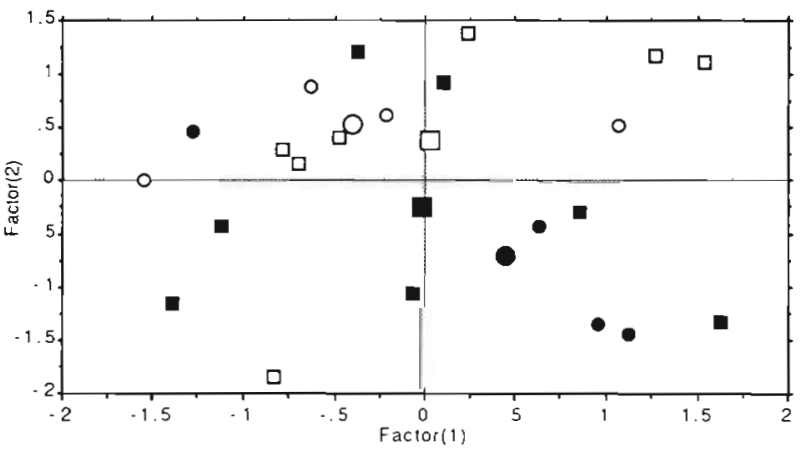

Fig. 5. Principal component scores of epifaunal samples for 2 sampling dates in 1986. The type of sample (cleared or control collected in the shallow or deep zones) is indicated. Means are represented by over-size symbols. Species loadings for factor axes are in Table $7 \mathrm{a}$

For both dates, average scores along one of the 2 factors differed significantly among depths (Table 6a) but scores for depth along the factors in question were too intermingled to warrant further consideration (Fig. 5a, b).

\section{Infauna}

One month after experimental clearing, the samples from manipulated plots had a significantly lower average score on the first factor than those from control plots, though there was not a clear separation (Fig. 6a, June 1986, Table 6b). Factor loadings showed the difference between the 2 sets of samples was due to a greater relative abundance of Gemma gemma and Spio $\mathrm{sp}$. on manipulated patches and a lower abundance of the remaining species except Tellina agilis (June 1986, Table $7 \mathrm{~b}$ ). This is indicated by the negative loadings of Gemma and Spio along Factor 1 (producing greater negativity of scores of the cleared plots) and positive a. JUNE 1986

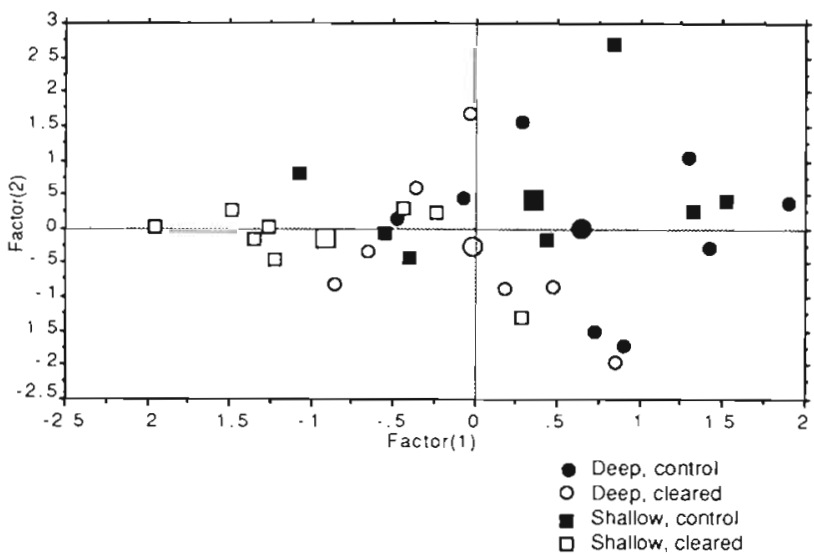

b. AUGUST 1986

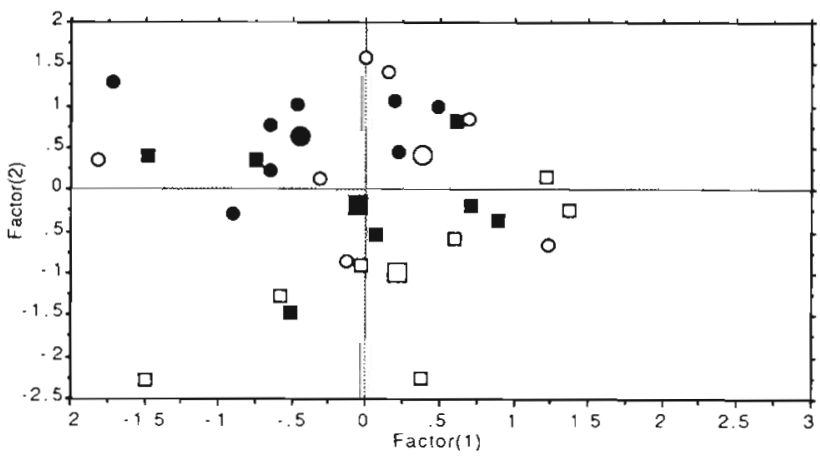

Fig. 6. Principal component scores of infaunal samples for 2 sampling dates in 1986. The type of sample (cleared or control collected in the shallow or deep zones) is indicated. Means are represented by over-size symbols. Species loadings for factor axes are in Table $7 \mathrm{~b}$

loading of most of the remaining species (producing the greater positivity of scores of the control plots). Tellina, which had a weighting near zero, did not contribute to the observed separation between experimental and control plots. Although the average scores were also significantly different between depth zones (June 1986, Table 6b), the scores of individual samples were too intermingled to warrant further consideration (Fig. 6a).

Three months after clearing there was no clear separation between manipulated and control samples though the average scores of control and treatment samples were significantly different along Factor 2 (August 1986, Table 6b). Separation between the deep and shallow zones, regardless of treatment, was marked along this factor and average scores were significantly different. This effect arose due to relatively higher numbers of certain species, particularly Gemma gemma and lower numbers of others such as Tellina agilis in the manipulated patches and/or the shallow zone (August 1986, Table $7 \mathrm{~b}$ ). 
Table 6. F-values of ANOVA comparing principal component factor scores between control and experimentally cleared patches. ANOVA was performed using the following factors; 'Depth' = position in either shallow or deep zone: and ' $T$ rt' = treatment, i.e. experimentally cleared vs control. $\cdots p<0.01$;

$$
\cdot 0.01<\mathrm{p}<0.05
$$

\begin{tabular}{|c|c|c|c|}
\hline & Depth & Trt & $\begin{array}{c}\text { Depth } \times \\
\text { Trt }\end{array}$ \\
\hline \multicolumn{4}{|l|}{ (a) Epifauna } \\
\hline \multicolumn{4}{|l|}{ July 1986} \\
\hline $\overrightarrow{\text { Degrees }}$ of freedom & 1 & 1 & 2 \\
\hline Factor (1) & $6.3^{\circ}$ & $29.6^{\cdots}$ & 0.5 \\
\hline Factor (2) & 3.2 & $12.6^{\cdots}$ & 0.3 \\
\hline \multicolumn{4}{|l|}{ September 1986} \\
\hline Degrees of freedom & 1 & 1 & 2 \\
\hline Factor $\{1\}$ & 0.0 & 0.4 & 0.7 \\
\hline Factor (2) & 0.1 & $5.1^{\circ}$ & 0.3 \\
\hline \multicolumn{4}{|l|}{ (b) Infauna } \\
\hline \multicolumn{4}{|l|}{ June 1986} \\
\hline Degrees of freedom & 1 & 1 & 2 \\
\hline Factor (1) & $5.3^{\circ}$ & $12.4^{\cdots}$ & 0.61 \\
\hline Factor (2) & 0.9 & 1.9 & 0.1 \\
\hline \multicolumn{4}{|l|}{ August 1986} \\
\hline Degrees of freedom & 1 & 1 & 2 \\
\hline Factor (1) & 0.1 & 1.9 & 0.4 \\
\hline Factor (2) & $15.2^{\cdots}$ & $4.7^{\circ}$ & 1.0 \\
\hline
\end{tabular}

\section{Comparison of diversity and richness on manipulated and control patches}

Average epifaunal diversity and richness are shown in Fig. 7 a. The numbers indicate that in every case the average diversity was lower on manipulated patches, but analysis of variance (Table $8 \mathrm{a}$ ) showed that overall the effect of manipulation was not significant. Similarly with richness, no significant effects were observed (Table 8a).

For infauna, the average diversity was significantly lower in manipulated than in control samples (Fig. $7 \mathrm{~b}$, Table $8 \mathrm{~b}$ ). Clearing also significantly reduced species richness in deep and shallow sites but this effect changed with time (significant time $\times$ treatment interaction, Table $8 \mathrm{~b}$ ), disappearing by the $3.0 \mathrm{mo}$ sampling date.

\section{DISCUSSION}

Experimental clearing showed that eelgrass was relatively slow to colonize bare patches, having a considerably lower average biomass after 4 mo of the growing season, and even a year later having a reduced biomass compared with controls. It was there- fore surprising to find that the invertebrate fauna showed much less response to clearing, since eelgrass is known to be of fundamental importance to the faunal community (e.g. Heck \& Orth 1980, Stoner 1980). Total infaunal numbers were not decreased by clearing, and only one of 3 species examined individually was lower than in controls 1.0 mo after clearing. One clam, Gemma gemma, became more abundant on cleared patches. Epifaunal numbers showed greater response, as could be expected for organisms directly associated with vegetation. Total epifaunal numbers, and abundances of 2 of 3 individual species examined, were significantly lower on cleared patches $1.5 \mathrm{mo}$ after clearing, but these had fully recovered by 4 mo after clearing.

For the epifauna, the key to this recovery appears to have been the colonization of bare patches by macroalgae. The colonizing algal species were the same as those that occurred in the surrounding undisturbed

Table 7 Amount of variation explained by first 2 factors of the PCA and standardized factor loadings showing the relative weights assigned to species

(a) Epifauna

Sampling time

July $1986 \quad$ September 1986

\begin{tabular}{|c|c|c|c|c|}
\hline Factor number & 1 & 2 & 1 & 2 \\
\hline $\begin{array}{l}\% \text { variation explained } \\
\text { by factor }\end{array}$ & 38 & 18 & 30 & 24 \\
\hline Ampithoe spp. & 0.80 & -0.34 & 0.17 & 0.61 \\
\hline Bittium alternatum & 0.75 & -0.05 & 0.21 & 0.63 \\
\hline Corophium insidiosum & 0.62 & 0.58 & 0.88 & -0.12 \\
\hline Gammarus mucronatus & 0.66 & 0.37 & 0.84 & -0.08 \\
\hline Gemma gemma & -0.11 & 0.85 & 0.52 & 0.33 \\
\hline Idotea baltica & 0.65 & -0.39 & -0.13 & 0.17 \\
\hline ldotea phosphorea & 0.44 & -0.36 & 0.45 & 0.59 \\
\hline Jaera marina & 0.43 & -0.21 & 0.28 & -0.79 \\
\hline Leptochelia rapax & 0.63 & 0.54 & 0.43 & 0.69 \\
\hline Mitrella lunata & 0.86 & -0.23 & 0.67 & 0.13 \\
\hline Mytilus edulis & 0.67 & 0.02 & 0.57 & -0.62 \\
\hline Nereis succinea & 0.37 & 0.38 & 0.71 & -0.39 \\
\hline
\end{tabular}

(b) Infauna

Sampling time June 1986 August 1986

Factor number

$\%$ variation explained by factor.

Gemma gemma

Heteroclitus sp.

Mytilus edulis

Nereis succinea

Petricola pholadiformis

Spio sp.

Tellina agilis

(1)

12

$\begin{array}{rrrr}1 & 2 & 1 & 2 \\ 32 & 21 & 22 & 21\end{array}$

$0.33+0.47$

$0.41-0.68$

$\begin{array}{llll}0.43 & -0.53 & 0.66 & -0.19\end{array}$

$\begin{array}{llll}0.71 & -0.30 & -0.38 & 0.45\end{array}$

$\begin{array}{llll}0.85 & 0.24 & -0.53 & -0.15\end{array}$

$\begin{array}{llll}0.66 & 0.41 & -0.45 & -0.19\end{array}$

$\begin{array}{rrrr}0.66 & 0.41 & -0.45 & -0.19 \\ -0.46 & 0.42 & 0.65 & 0.17 \\ 0.15 & 0.79 & 0.38 & 0.75\end{array}$

$\begin{array}{lllll}0.15 & 0.79 & 0.38 & 0.75\end{array}$ 
CONTROL CLEARED
Fig. 7. Average diversity (ShannonWiener Index) and richness (no. of species) per sample of epifauna and infauna on control and experimentally manipulated patches. 'Deep' and 'Shal.' (shallow) are the 2 depth zones. Bars indicate standard errors. Number of replicates is shown beneath each column a. EPIFAUNA
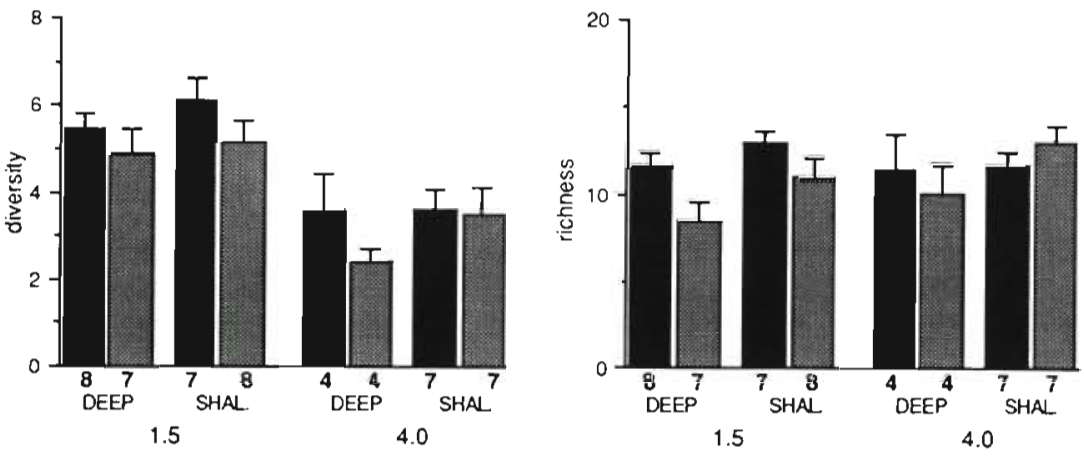

MONTHS AFTER CLEARING

b. INFAUNA
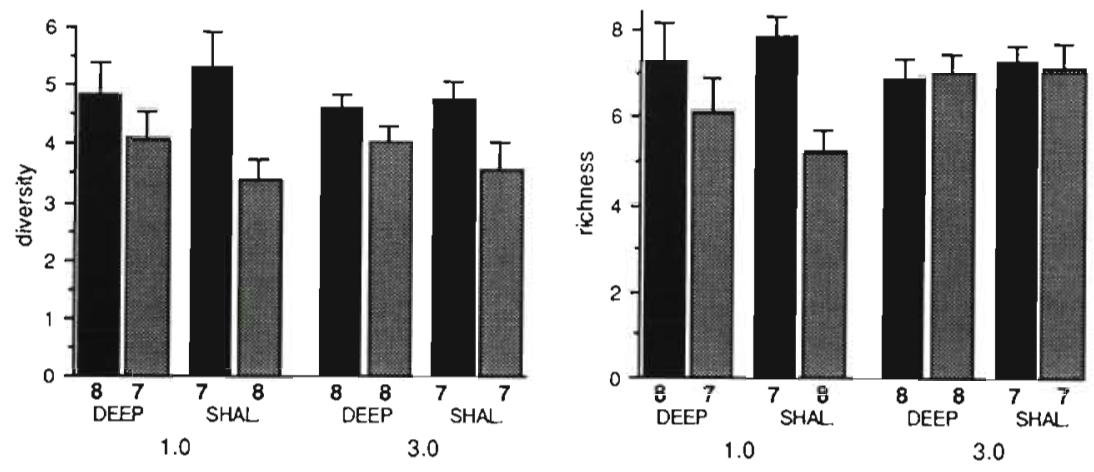

MONTHS AFTER CLEARING

Table 8. F-values of ANOVA comparing diversity and richness on control and experimentally cleared patches. The factors were: 'Time' = time of sampling; 'Depth' = position in shallow or deep zone; and 'Trt' = treatment, ie. experimentally cleared vs control. $\cdots p<0.01 ; \cdot 0.01<p<0.05$

\begin{tabular}{|c|c|c|c|c|c|c|c|}
\hline Variable & Time & Depth & Trt & $\begin{array}{l}\text { Time } \times \\
\text { Depth }\end{array}$ & $\begin{array}{c}\text { Time } \\
\text { Trt }\end{array}$ & $\begin{array}{c}\text { Depth } x \\
\text { Trt }\end{array}$ & $\begin{array}{l}\text { Time } x \\
\text { Depth } x \\
\text { Trt }\end{array}$ \\
\hline \multicolumn{8}{|l|}{ (a) Epifauna } \\
\hline Degrees of freedom & 1 & 1 & 1 & 1 & 1 & 1 & 1 \\
\hline Diversity & $35.7^{\cdots}$ & 1.9 & 3.6 & 0.0 & 0.0 & 0.1 & 1.0 \\
\hline Richness & 0.4 & $4.4^{\circ}$ & 2.7 & 0.1 & 2.3 & 1.6 & 0.2 \\
\hline \multicolumn{8}{|l|}{ (b) Infauna ( $n=60$ ) } \\
\hline Degrees of freedom & 1 & 1 & 1 & 1 & 1 & 1 & 1 \\
\hline Diversity & 0.3 & 0.2 & $14.0^{\circ}$ & 0.0 & 0.4 & 2.3 & 0.3 \\
\hline Richness & 1.2 & 0.0 & $5.2^{\circ}$ & 0.3 & $5.1^{\bullet}$ & 1.2 & 0.6 \\
\hline
\end{tabular}

eelgrass bed, in contrast to hard-bottom communities (e.g. Dethier 1984, Sousa 1985, Turner 1985) where colonists are often different from the neighbouring species. On the cleared patches, total epifaunal numbers, and abundances of each of the individual species examined, were found to be significantly related to either one of the 2 major algal groups which quickly returned to the cleared patches. In contrast, no positive relation to eelgrass biomass on the cleared patches was observed. 
Previous work has shown that epifaunal-macrophyte associations in this seagrass bed varied in intensity and the type of macrophyte favored (Schneider \& Mann 1991a). The recovery of specific invertebrate species following disturbance was dependent on the recovery of suitable macrophyte species. For example, the amphipod Gammarus was strongly associated with coarsely branched algae in the undisturbed eelgrass bed (Schneider \& Mann 1991a), explaining its rapid reappearance on experimentally cleared areas in conjunction with the influx of coarsely branched algae. In contrast, the tube-dwelling amphipod Ampithoe was associated with eelgrass or, when seasonally abundant, Sphaerotrichia (Schneider \& Mann 1991a). It recovered to control numbers on the cleared patches in September, 1986, because of the pronounced Sphaerotrichia bloom. Therefore, assessment of faunal responses to disturbance-induced changes in vegetation cover must incorporate not only the possibility of differential recovery by various macrophyte types, but also species-specific responses of invertebrates to macrophytes.

The more varied infaunal response to clearing reflects the absence of a direct relationship to vegetation as seen for the epifauna. The clam Gemma gemma, the one species which became more abundant in cleared patches, is characteristic of open areas and unstable sediments (Saunders et al. 1962), and thus appeared to be responding to the provision of suitable habitat on the cleared patches. Numbers of the remaining infaunal species were either unaffected or depressed 1.0 mo after clearing, but in any case had returned to control levels by the summer's end. The removal of eelgrass was expected to have a major impact because its root-rhizome mat has been previously demonstrated to stabilize the sediment and protect the infauna from predators (Peterson 1982). Casual observation indicated that the removal of the rootrhizome mat on such a small scale did not noticeably affect sediment stability. In areas where large predatory crabs occur, the root-rhizome mat is essential for the protection of many infaunal species (Blundon \& Kennedy 1982), but no such species occur in this system (Schneider \& Mann 1991b).

The experimental manipulations performed in this study demonstrated that the creation of small artificial gaps had a relatively short-lived effect in the depth zones investigated. Experimental clearing by raking accurately mimicked the total removal of above- and below-ground plant parts observed on naturally ice rafted patches. Two important differences between experimental clearing and natural ice scour are the season of clearing and the greater variation in the size and position of naturally cleared patches. Natural ice scour occurs during winter, while patches were experi- mentally cleared in early spring. Sediment erosion may be greater following natural ice scour during the winter than experimental clearing in spring, but casual observation did not reveal major erosion on either patch type. The difference in timing of natural and artificial patch creation probably did not have a direct impact on animal recolonization because animals in this eelgrass bed are quiescent during the winter and become active and reproduce during late spring and summer, numbers of recruits being highest in late summer and early fall (Schneider \& Mann 1991a).

Some natural ice-scoured patches were much larger than experimentally cleared ones (which represented the average dimensions of natural patches). Although not documented, it was noticed that the size ranges of animals colonizing the bare patches were about the same as those in the control samples. Migration of adults from surrounding vegetation thus appeared to be an important source of colonists and it has elsewhere been demonstrated that epifauna, even sedentary forms such as tubicolous amphipods, undertake frequent migrations (De Witt 1987) and many infaunal species including clams are also mobile (Sortin 1989). If animals move only short distances at one time, then recolonization by immigration of the central portions of larger ice-scoured areas would be slower than that observed for the small experimentally cleared patches.

In the natural seagrass bed, disturbance by ice rafting occurs in the shallow part of the experimental area but not in the deep part. Instances where cleared patches are more similar to control samples from the shallow than the deep zone could reflect the effects of natural ice scour in the shallow zone. Gemma gemma was more abundant in control samples from the shallow than the deep zone, and markedly more numerous on experimentally cleared patches. The absence of more widespread similarities between shallow control and experimentally cleared samples might have been because none of the control samples from the shallow zone coincided with patches which had been naturally cleared in the preceding winter. This suggests that natural ice scour does not have a long term impact on the faunal assemblage, a view supported by the observation that the faunal assemblage on the experimentally cleared patches was virtually indistinguishable from control samples by the summer's end.

In conclusion, the recovery of epifaunal and infaunal invertebrates after disturbance was more rapid than expected from eelgrass regrowth. The rapid re-establishment of macroalgae provided a suitable habitat for the epifauna. The removal of eelgrass on such a small scale does not appear to have a long-term impact on the infauna in this eelgrass community. 
Acknowledgements. Kathryn Cook and Tricia Murphy assisted in field work. F. I. Schneider was supported by an NSERC 1967 Science and Engineering Scholarship, and the research costs were met from an NSERC Operating Grant to K. H. Mann. The authors are grateful to Dr C. H. Peterson, whose editorial work resulted in considerable improvements in the paper

\section{LITERATURE CITED}

Austin, M. P. (1985). Continuum concept, ordination methods, and niche theory. Ann. Rev. Ecol. Syst. 16:39-61

Bertness, M. D., Ellison, A. M. (1987). Determinants of pattern in a New England salt marsh plant community. Ecol. Monogr. 57: 129-147

Blundon, J. A., Kennedy, V S. (1982). Refuges for infaunal bivalves from blue crab, Callinectes sapidus (Rathbun), predation in Chesapeake Bay. J. exp. mar. Biol. Ecol. 65: 67-81

Bronmark, C. (1985). Freshwater snail diversity: effects of pond area, habitat heterogeneity and isolation. Oecologia 67: 127-131

Coen, L. D., Heck, K. L. Jr, Abele, L. G. (1981). Experiments on competition and predation among shrimps of seagrass meadows. Ecology 62: 1484-1493

Crome, F. H. J., Richards, G. C. (1988). Bats and gaps: microchiropteran community structure in a Queensland rain forest. Ecology 69: 1960-1969

Crowder, L. B., Cooper, W. E. (1982). Habitat structural complexity and the interaction between bluegills and their prey. Ecology 63: 1802-1813

Dethier, M. N. (1984). Disturbance and recovery in intertidal pools: maintenance of mosaic patterns. Ecol. Monogr 54 : 99-118

DeWitt, T H. (1987). Microhabitat selection and colonization rates of a benthic amphipod. Mar Ecol. Prog. Ser. 36: $237-250$

Friday, L. E. (1987). The diversity of macroinvertebrate and macrophyte communities in ponds. Freshwat. Biol. 18: $87-104$

Hay, M. E., Duffy, J. E., Fenical, W., Gustafson, K. (1988). Chemical defense in the seaweed Dictyopteris delicaluta. differential effects against reef fishes and amphipods. Mar. Ecol, Prog. Ser 48: 185-192

Heck, K. L. Jr, Orth, R. J. (1980). Seagrass habitats: the roles of habitat complexity, competition and predation in structuring associated fish and motile macroinvertebrate assemblages. In: Kennedy, V S. (ed.) Estuarine perspectives. Academic Press, New York, p. 449-464

Heck, K. L. Jr, Thoman, T. A. (1981). Experiments on predatorprey interactions in vegetated aquatic habitats. J. exp mar. Biol. Ecol. 53: 125-134

Heine, J. N. (1989). Effects of ice scour on the structure of sublittoral marine algal assemblages of St. Lawrence and St. Matthew Islands, Alaska. Mar Ecol. Prog. Ser 52: $253-260$

Hobbs, R. J., Mooney, H. A. (1985). Community and population dynamics of serpentine grassland annuals in relation to gopher disturbance. Oecologia 67.342-351.

Holt, S. A., Kitting, C. L., Arnold, C. R. (1983). Distribution of young red drums among different seagrass meadows. Trans. Am. Fish. Soc. 112: 267-271

Hurlbert, S. H. (1984). Pseudoreplication and the design of ecological field experiments. Ecol. Monogr. 54: 187-211

Joyce, A. A., Weisberg, S. B. (1986). The effects of predation by the mummichog. Fundulus heteroclitus (L.), on the abundance and distribution of the salt marsh snail, Melam pus bidentatus (Say). J. exp. mar. Biol. Ecol. 100: 295-306

Kennelly, S. J. (1987). Physical disturbances in an Australian kelp community. I. Temporal effects. Mar Ecol. Prog. Ser 40: $145-153$

Leber, K. M. (1985). The influence of predatory decapods, refuge, and microhabitat selection on seagrass communities. Ecology 66: 1951-1964

Lewis, F. G. (1984). Distribution of macrobenthic crustaceans associated with Thalassia, Halodule and bare sand substrata. Mar. Ecol. Prog. Ser 19: 101-113

Lewis, F. G. (1987). Crustacean epifauna of seagrass and macroalgae in Apalachee Bay, Florida, USA. Mar Biol. 94: 219-229

Lewis, F. G., Stoner, A. W (1983). Distribution of macrofauna within seagrass beds: an explanation for patterns of abundance. Bull. mar. Sci. 33: 296-304

McRoy, C. P., Helfferich, C. (1980). Applied aspects of seagrasses. In: Phillips, R. C., McRoy, C. P. (eds.) Handbook of seagrass biology: an ecosystem perspective. Garland STPM Press, New York, p. 297-343

Mills, J. N. (1986). Herbivores and early postfire succession in southern California chaparral. Ecology 67: 1637-1649

Nelson, W. G. (1979). Experimental studies of selective predation on amphipods: consequences for amphipod distribution and abundance. J. exp. mar Biol. Ecol. 38: 225-245

Nicotri, M. E. (1980). Factors involved in herbivore food preference. J. exp. mar Biol. Ecol. 42: 13-26

Norton, T A., Benson, M. R. (1983). Ecological interactions between the brown seaweed Sargassum muticum and its associated fauna. Mar Biol. 75: 169-177

Orth, R. J. (1977). The importance of sediment stability in seagrass communities. In. Coull, B. C. (ed.) Ecology of marine benthos. Univ, of S. Carolina Press, Columbia, p. 281-300

Orth, R. J., Heck, K. L. Jr, Van Montfrans, J. (1984). Faunal communities in seagrass beds: a review of the influence of plant structure and prey characteristics on predatory-prey relationships. Estuaries 7: 339-350

Patriquin, D. G. (1975). 'Migration' of blowouts in seagrass beds at Barbados and Carriacou, West Indies, and its ecological and geological implications. Aquat. Bot. 1 163-189

Peet, R. K. (1974). The measurement of species diversity. Ann. Rev. Ecol. Syst. 5: 285-307

Peterson, C. H. (1982). Clam predation by whelks (Busycon spp.): experimental tests of the importance of prey size prey density and seagrass cover Mar Biol. 66: 159-170

Peterson, C. H., Summerson, H. C., Duncan, P. B. (1984). The influence of seagrass cover on population structure and individual growth rate of a suspension-feeding bivalve, Mercenaria mercenaria. J. mar. Res. 42: 123-138

Pielou, E. C. (1984). The interpretation of ecological data: a primer on classification and ordination. John Wiley and Sons, New York

Robertson, A. I., Mann, K. H. (1984). Disturbance by ice and life-history adaptations of the seagrass Zostera marina. Mar Biol 80: 131-141

Runkle, J. R. (1985). Disturbance regimes in temperate forests In: Pickett, S. T A., White, P. S. (eds.) The ecology of disturbance and patch dynamics. Academic Press, New York, p. 17-33

Saunders, H. L., Geudsmit, E., Mills, L., Hampson, G. G (1962). A study of the intertidal fauna of Barnstable Harbour, Massachusetts. Limnol. Oceanogr 7: 63-79

Schneider, F. I. (1990). The response of invertebrates to the 
disturbance of a seagrass bed by simulated ice rafting. $\mathrm{Ph}$.D. thesis, Dalhousie University, Halifax, Nova Scotia

Schneider, F. I., Mann, K. H. (1991a). Species specific relationships of invertebrates to vegetation in a seagrass bed: 1 . Correlational studies. J. exp. mar. Biol. Ecol. 145: 101-117 Schneider, F. I., Mann, K. H. (1991b). Species specific relationships of invertebrates to vegetation in seagrass beds. II. Experiments on the importance of macrophyte shape, epiphyte cover and predation. J. exp. mar. Biol. Ecol. 145: $119-139$

Sortin, T (1989). Floating behavior in the tellinid bivalve Macoma baltica (L.). Oecologia 77: 273-277

Sousa, W. P. (1979). Experimental investigations of disturbance and ecological succession in a rocky intertidal algal community. Ecol. Monogr. 49: 227-254

Sousa, W. P. (1985). Disturbance and patch dynamics on rocky intertidal shores. In: Pickett, S. T. A., White, P. S. (eds.) The ecology of natural disturbance and patch dynamics. Academic Press, New York, p. 101-124

Stoner, A. W (1980). The role of seagrass biomass in the organization of benthic macrofaunal assemblages. Bull. mar. Sci. 30: 537-551

Summerson, H. C., Peterson, C. H. (1984). Role of predation in

This article was presented by C. H. Peterson, Morehead City, N. Carolina, USA organizing benthic communities of a temperate-zone seagrass bed. Mar Ecol. Prog. Ser. 15: 63-77

Turner, T (1985). Stability of rocky intertidal surfgrass beds: persistence, preemption, and recovery. Ecology 66: 83-92

Virnstein, R. W., Howard, R. K. (1987a). The motile epifauna of marine macrophytes in the Indian River lagoon, Florida. I. Comparisons among three species of seagrasses from adjacent beds. Bull. mar Sci. 41: 1-12

Virnstein, R. W., Howard, R. K. (1987b). The motile epifauna of marine macrophytes in the Indian River lagoon, Florida. II Comparisons between drift algae and three species of seagrasses. Bull. mar. Sci. 41:13-26

White, P. S., Pickett, S. T A. (1985). Natural disturbance and patch dynamics: an introduction. In: Pickett, S. T A., White, P. S. (eds.) The ecology of natural disturbance and patch dynamics. Academic Press, New York, p. 3-13

Williams, S. L. (1988). Thalassia testudinum productivity and grazing by green turtles in a highly disturbed seagrass bed. Mar. Biol. 98: 447-455

Zimmerman, R., Minello, T J. (1984). Densities of Penaeus aztecus, Penaeus setiferus, and other natant macrofauna in a Texas salt marsh. Estuaries 7: 421-433

Manuscript first received: September 28, 1990 Revised version accepted: September 17, 1991 